\title{
Effects of different fermentation parameters on quality characteristics of kefir
}

\author{
Tuğba Kök-Taş, ${ }^{* 1}$ Atıf C. Seydim, ${ }^{*}$ Barbaros Özer,† and Zeynep B. Guzel-Seydim* \\ *Department of Food Engineering, Faculty of Engineering and Architecture, Suleyman Demirel University, Cunur, 32260 Isparta, Turkey \\ †Department of Dairy Technology, Faculty of Agricultural, Ankara University, Dıskapi, 06110 Ankara, Turkey
}

\section{ABSTRACT}

The main objective of the study was to determine the effects of different fermentation parameters on kefir quality. Kefir samples were produced using kefir grains or natural kefir starter culture, and fermentation was carried out under normal or modified atmosphere $(10 \%$ $\mathrm{CO}_{2}$ ) conditions. The microbiological (lactobacilli, lactococci, Lactobacillus acidophilus, Bifidobacterium spp., and yeasts), chemical ( $\mathrm{pH}$, lactic acid, total solids, protein, ethanol, exopolysaccharide contents), rheological, and sensory properties of kefir samples were investigated during a 21-d storage period. The use of different fermentation parameters or the choice of grain versus natural kefir starter culture did not significantly affect the content of microorganisms. Lactobacilli, lactococci, and yeast contents of kefir samples varied between 9.21 and $9.28,9.23$ and 9.29 , and 4.71 and $5.53 \log \mathrm{cfu} / \mathrm{mL}$, respectively, on d 1 of storage. Contents of L. acidophilus and Bifidobacterium spp. were between 5.78 and 6.43 and between 3.19 and $6.14 \log \mathrm{cfu} / \mathrm{mL}$, respectively, during $21 \mathrm{~d}$ of storage. During the storage period, $\mathrm{pH}$, lactic acid (\%), total solids (\%), protein (\%), acetaldehyde, and ethanol contents of kefir samples ranged from 4.29 to 4.53 , from 0.81 to $0.95 \%$, from 7.81 to $8.21 \%$, from 3.09 to $3.48 \%$, from 3.8 to $23.6 \mathrm{mg} / \mathrm{L}$, and from 76.5 to $5,147 \mathrm{mg} / \mathrm{L}$, respectively. The exopolysaccharide contents of the samples decreased during 21 d of cold storage; the samples fermented under modified atmosphere had relatively higher exopolysaccharide contents, indicating higher potential therapeutic properties. The kefir samples exhibited non-Newtonian pseudoplastic flow behavior according to the power law model. According to the sensory results, kefir produced from natural kefir starter culture under $\mathrm{CO}_{2}$ atmosphere had the highest overall evaluation score at $\mathrm{d} 1$.

Key words: kefir, exopolysaccharide, viscosity, sensory

Received May 21, 2012.

Accepted October 28, 2012

${ }^{1}$ Corresponding author: tugbakoktas@sdu.edu.tr

\section{INTRODUCTION}

Kefir is a self-carbonated, refreshing, fermented milk that has unique sensory properties due to a mixture of lactic acid, acetaldehyde, acetoin, ethanol, and other fermentation by-products obtained from a diverse range of microorganisms inherent in kefir grains (Guzel-Seydim et al., 2011). During fermentation, lactic acid bacteria (LAB) convert lactose to lactic acid and other flavor compounds, and lactose-fermenting yeasts produce $\mathrm{CO}_{2}$ and small amounts of ethanol. Kefir has a mildly sour and yeasty flavor with a tangy effervescence depending on the composition of the kefir grains or kefir starter culture (Ertekin and Guzel-Seydim, 2010). Kefir grain is a unique natural starter culture for kefir production. Kefir grains are gelatinous granules, 2 to $15 \mathrm{~mm}$ in diameter, consisting of a mixture of microorganisms grouped in a highly organized manner. Kefir grains consist of a blend of LAB, acetic acid bacteria, and yeasts (Wszolek et al., 2006). Kefir can also be produced from natural kefir starter culture, which is obtained from kefir grains. In the preparation of natural kefir culture, kefir grains $(2-3 \%$, wt/vol) are fermented in reconstituted milk at 20 to $25^{\circ} \mathrm{C}$ for about $24 \mathrm{~h}$. The grains are removed and the remaining fermented liquid is aseptically stored at $4^{\circ} \mathrm{C}$ (Guzel-Seydim et al., 2010). Kefir starter cultures, consisting of a limited variety of pure biotechnologically produced microorganisms, have been used for industrial applications. However, kefir produced with starter culture differs from natural kefir produced from kefir grains because of the loss of characteristic properties of traditional kefir, including the organoleptic qualities and the health benefits, due to the relatively inadequate microflora in custom-made, defined starter cultures.

The microflora of kefir grains is held together in a unique matrix of protein and exopolysaccharide material (EPS; Rimada and Abraham, 2001; Frengova et al., 2002). The EPS produced by kefir microorganisms is commonly known as kefiran, which is a water-soluble, branched glucogalactan consisting of equal amounts of D-glucose and D-galactose (Micheli et al., 1999; Mitsue et al., 1999). Kefiran is present in the capsular material of some large, rod-like bacteria, especially lactobacilli. Lactobacillus kefir, Lactobacillus parakefir, and Lacto- 
bacillus kefiranofaciens are the major EPS-producing bacteria present in kefir grain microflora (Cheirsilp et al., 2003a,b; Wang et al., 2008). The EPS produced by kefir microorganisms improves the texture and mouthfeel of the product. In recent years, the use of kefiran in the food industry as a food-grade gum and fortification agent and in the development of novel packaging materials has gained popularity (Kwon et al., 2006; Rimada and Abraham, 2006; Piermaria et al., 2009). Kefiran may have therapeutic immunostimulatory, antimutagenic, antiallergic, and antiulcer activities, and might act as a prebiotic compound (Yoon et al., 1999; WonHo et al., 2003).

Fermentation parameters, such as type of kefir culture (from natural grains or starter cultures), inoculation ratio, temperature, and time, affect the final microbial, chemical, and sensory quality of kefir. Atmospheric oxygen may affect growth and balance (ratio of microorganisms) in kefir microflora. Several methods exist for measuring the viability of LAB, especially Bifidobacteria spp. and Lactobacillus acidophilus (Scardovi, 1986; Shah, 2000), because of the presence of mainly microaerophilic and anaerobic microflora in kefir grains. The aim of this study was to investigate the effects of different fermentation parameters - kefir grain versus natural kefir starter culture obtained from kefir grains and $\mathrm{CO}_{2}$ atmosphere during fermentationon the microbiological, chemical, sensory, and rheological properties of kefir during a 21-d storage period.

\section{MATERIALS AND METHODS}

\section{Materials}

Kefir grains were obtained from the Department of Food Engineering, Suleyman Demirel University (Isparta, Turkey). Cow milk was supplied from Suleyman Demirel University Ünsüt Dairy Plant. All chemicals were of analytical grade and were from Sigma-Aldrich Co. (St. Louis, MO).

\section{Preparation of Kefir Samples}

Kefir grains (KG) and natural kefir starter culture (KS) were used to ferment milk for kefir production. Natural kefir starter was obtained from kefir grains by straining after first fermentation at $25^{\circ} \mathrm{C}$ for approximately $22 \mathrm{~h}$, and the fermentation was ended at $\mathrm{pH} 4.6$ (Figure 1). Fermentation time $(22 \mathrm{~h})$ between $\mathrm{KG}$ and KS was identical. The inoculation rate of culture was decided after preliminary sensory studies. Kefir samples cultured with different inoculation rates $(2,3$, and $5 \%)$ were evaluated by a sensory panel of 11 experienced panelists; according to their overall evaluation (taste, smell, texture, and appearence), optimal inoculation rates for $\mathrm{KG}$ and $\mathrm{KS}$ were $2 \%$ (wt/vol) and $3 \%$ (wt/ vol), respectively. The inoculated kefir milk was fermented under normal atmospheric condition (KG and $\mathrm{KS}$ ) or under $10 \% \mathrm{CO}_{2}$ (KG-C and $\left.\mathbf{K S}-\mathbf{C}\right)$ at $25^{\circ} \mathrm{C}$. Fermentation under $\mathrm{CO}_{2}$ was achieved by using a $\mathrm{CO}_{2}$ generator (CO-150, New Brunswick Scientific, Enfield, $\mathrm{CT}$ ). The rate of $\mathrm{CO}_{2}$ was determined, after preliminary studies, according to LAB growth. The $\mathrm{pH}$ was measured using a combined-electrode $\mathrm{pH}$ meter (WTW Measurement Systems, Fort Myers, FL). Fermentation was ended at $\mathrm{pH} 4.6$ and the samples were stored at $4^{\circ} \mathrm{C}$ for $21 \mathrm{~d}$.

\section{Microbiological Analysis}

Lactobacilli counts were determined on de Man, Rogosa, and Sharpe (MRS) medium (Merck, Darmstadt, Germany) after incubation at $37^{\circ} \mathrm{C}$ under anaerobic conditions $\left(6 \% \mathrm{CO}_{2}\right)$ for $3 \mathrm{~d}$. Lactic streptococci were enumerated on M17 medium (Merck) at $37^{\circ} \mathrm{C}$ under anaerobic conditions $\left(6 \% \mathrm{CO}_{2}\right)$ for $2 \mathrm{~d}$. Yeasts were grown on potato dextrose agar (Merck) with addition of $0.14 \%$ lactic acid at $25^{\circ} \mathrm{C}$ for $5 \mathrm{~d}$ (Mossel et al., 1995). Lactobacillus acidophilus were determined on MRS with addition of $10 \%$ (wt/vol) sorbitol (Shah, 2000) and Bifidobacterium spp. were grown on MRS with neomycin, nalidixic acid, lithium chloride, and paromomycine sulfate (MRS-NNLP; Shah, 2000) at $37^{\circ} \mathrm{C}$ under anaerobic conditions $\left(6 \% \mathrm{CO}_{2}\right)$ for $3 \mathrm{~d}$.

\section{Proximate Analysis}

Titratable acidity, DM, protein, lactic acid, and fat were determined according to AOAC International (1992) methods. Acetaldehyde and ethanol contents of samples were determined by using a headspace (Turbo Matriks 16, Perkin Elmer, Waltham, MA) gas chromatographic (Auto System XL, Perkin Elmer) method that used the flame-ionization detector, according to Guzel-Seydim et al. (2000).

\section{Purification and Quantification of EPS}

The separation and quantification of EPS was carried out according to Zisu and Shah (2003). The proteins in $50 \mathrm{~mL}$ of diluted kefir sample were precipitated with 2 $\mathrm{mL}$ of $20 \%$ (wt/vol) TCA and separated by centrifugation (Sorvall RT7, Kendro Instruments Australia Pty Ltd., Lane Cove, NSW, Australia) at $3,313 \times g$ for 30 min at $4^{\circ} \mathrm{C}$. The $\mathrm{pH}$ of the supernatant was adjusted to 6.8 with $40 \%$ (wt/vol) $\mathrm{NaOH}$, and then boiled in a sealed container at $100^{\circ} \mathrm{C}$ for $30 \mathrm{~min}$ to denature the whey proteins. The denatured whey proteins were re- 


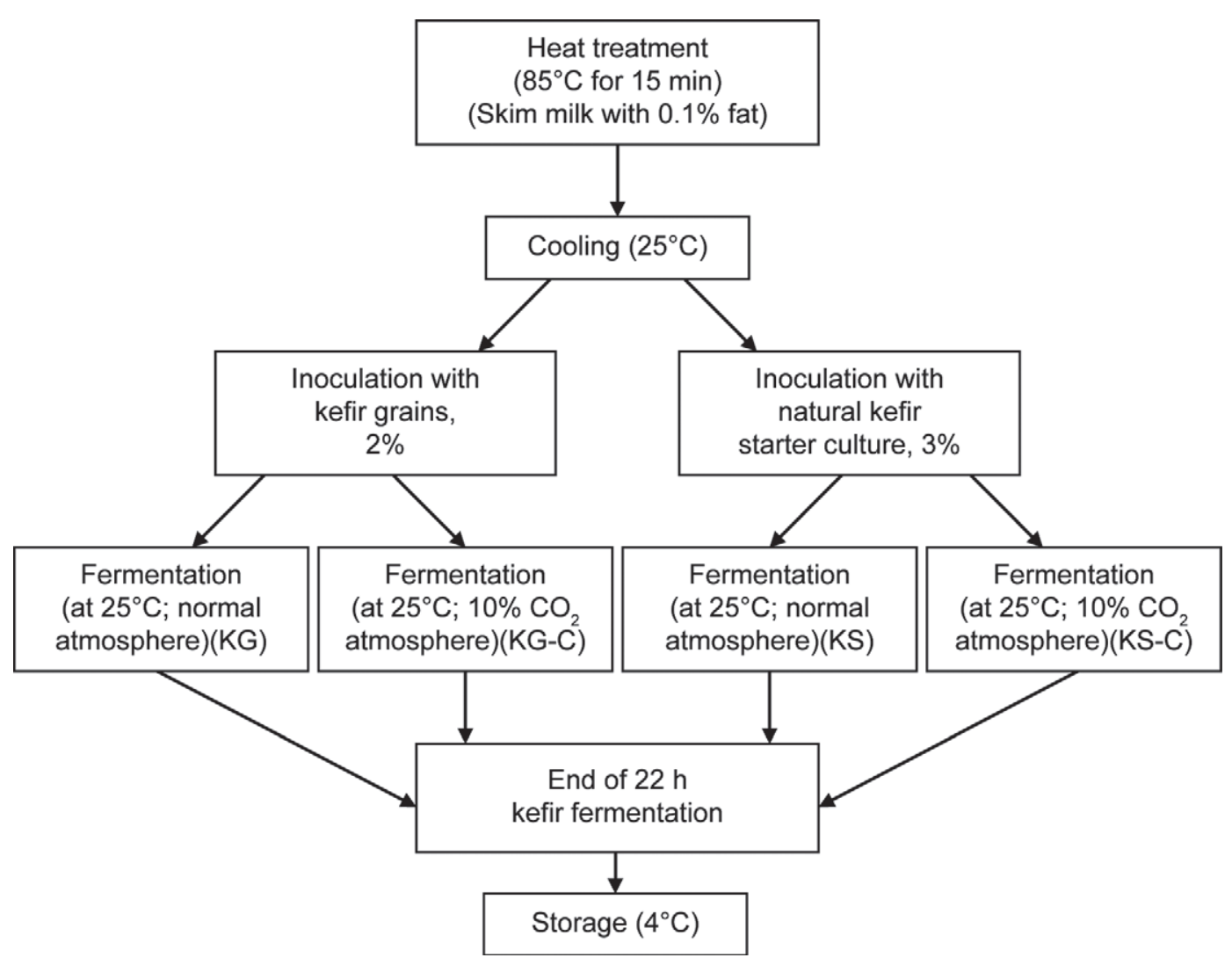

Figure 1. Flow scheme of kefir sample production and experimental design: KG = kefir produced from kefir grains at normal atmosphere, $\mathrm{KG}-\mathrm{C}=$ kefir produced from kefir grains in $10 \% \mathrm{CO}_{2}$ atmosphere, $\mathrm{KS}=$ kefir produced from natural kefir starter culture at normal atmosphere, and $\mathrm{KS}-\mathrm{C}=$ kefir produced from natural kefir starter culture in $10 \% \mathrm{CO}_{2}$ atmosphere.

moved by centrifugation (at $3,313 \times g, 30 \mathrm{~min}, 4^{\circ} \mathrm{C}$ ). The remaining carbonhydrate pellet was resuspended in $10 \mathrm{~mL}$ of deionized $\mathrm{H}_{2} \mathrm{O}$ and the suspension was sonicated for $1 \mathrm{~h}$ at $24^{\circ} \mathrm{C}$ using a sonication bath (FX 14PH sonication bath; Unisonics Pty Ltd., Sydney, Australia). The suspension was dialysed in a dialysis membrane tube with molecular weight cut-off of 12,000 Da (Carolina Biological Supply Company, Burlington, $\mathrm{NC}$ ) against tap water at $4^{\circ} \mathrm{C}$ for $2 \mathrm{wk}$; the water was changed twice a day. The concentration of EPS in the suspension after dialysis was quantified using the phenol-sulfuric method and was expressed in glucose equivalents (mg/L; Cerning, 1995).

\section{Rheological Analyses}

Rheological analyses were carried out using a Brookfield Rotational Rheometer (model DV-II Pro LV; Brookfield Engineering Laboratories, Middleboro, MA) according to the modified method of Penna et al. (2001) as used in Ertekin and Guzel-Seydim (2010) and Kök-Taş and Güzel-Seydim (2010). The Brookfield rheometer with a small sample adapter was fixed with spindle SC4-18. The shear rate, shear stress, and viscosity were measured at rotational speeds from 10 to 50 rpm, increasing by $2 \mathrm{rpm}$ every $5 \mathrm{~s}$. Duplicate analyses were carried out at $4^{\circ} \mathrm{C}$, and the data obtained were processed using Rheocalc Application Software (V3.2 Build 47-0; Brookfield Engineering Laboratories). The features of the flow curves were determined using the power-law model.

\section{Sensory Analysis}

Sensory evaluations were conducted using an 11-member panel in the Department of Food Engineering at Suleyman Demirel University (Isparta, Turkey). Panelists were selected from volunteer graduate students and academic staff of the Department of Food Engineering. The panelists $(\mathrm{n}=11)$ received a 30 -h training session on descriptive analysis technique, including basic tastes and flavor identification, and using a 10-point product specific scale with references (Meilgaard et al., 1999). The attributes regarding effects of the different treatments in kefir production were determined with panelists and the panel leader before the experiment 
started (Uysal et al., 2004). Kefir samples (100 mL) were served and presented to the panelists in cups bearing a random 3-digit number; each sample was scored individually. Samples were presented to the panelists in individual plastic cups, and bread sticks and a glass of water were given between each sample. Sensory evaluation was based on 10-point scales from $0=$ absence of the attribute, to $10=$ extremely high intensity of the attribute. Serving order was completely randomized. The sensory attributes appearance, color, aroma, flavor, texture, odor, and overall acceptability were evaluated. Four kefir samples were presented to the panel group at each session.

\section{Statistical Analyses}

All analyses were replicated 3 times and performed in duplicate. The data were analyzed using SPSS Base 16.0 (SPSS Inc., Chicago, IL). Results for the analyses of rheological parameters and EPS content of samples were statistically evaluated by repeated-measures variance analyses technique. Differences within groups were determined by Tukey test, a multiple comparison test.

\section{RESULTS AND DISCUSSION}

\section{Microbiological Contents of Kefir Samples}

Kefir samples were examined at 1, 7, 14, and $21 \mathrm{~d}$ of cold storage. The contents of LAB, lactococci, and yeasts in KG, KG-C, KS, and KS-C samples are presented in Table 1. The KG-C samples had the highest lactobacilli counts $(P<0.05)$ followed by KS, KS-C, and KG. In agreement with our findings, the literature reports counts of lactobacilli and lactococci in kefir of $10^{8}$ and $10^{9} \mathrm{cfu} / \mathrm{mL}$, respectively (Rosi and Rossi, 1978; Kandler and Kunath, 1983; Rea et al., 1996; Motaghi et al., 1997; Kılıç et al., 1999; Witthuhn et al., 2004; Guzel-Seydim et al., 2005). However, Simova et al. (2002) reported that the proportion of streptococci in the total kefir microflora increased by 26 to $30 \%$, whereas that of lactobacilli decreased by 13 to $23 \%$, in contrast to our findings. Yeast contents of KG and KG-C were 5.50 and $5.53 \log \mathrm{cfu} / \mathrm{mL}(P>0.05)$, whereas those of $\mathrm{KS}$ and KS-C samples were 4.77 and $4.71 \log \mathrm{cfu} / \mathrm{mL}$, respectively (Table 1). Yeast content differed significantly between KS and KG samples $(P<0.05)$, whereas application of $\mathrm{CO}_{2}$ did not show any adverse effects on yeast content $(P>0.05)$. A reduced yeast population in the product could limit the amount of swelling in the packages, which would solve a significant problem in the kefir industry (Guzel-Seydim et al., 2010).The yeast level was $10^{5} \mathrm{cfu} / \mathrm{mL}$, in line with that recorded by Guzel-Seydim et al. (2010) and Kılıç et al. (1999).

Counts of L. acidophilus and Bifidobacterium spp. of kefir samples are shown in Figure 2. A significant decrease occurred in L. acidophilus and Bifidobacterium spp. counts during cold storage $(P<0.05)$. Counts of $L$. acidophilus in KG-C and KS-C samples were 6.55 and $6.42 \log \mathrm{cfu} / \mathrm{mL}$, respectively (Figure 2a), and those of Bifidobacterium spp. were 6.14 and $5.90 \mathrm{log}$ cfu/ $\mathrm{mL}$, respectively (Figure $2 \mathrm{~b}$ ). Lactobacillus acidophilus is microaerophilic and Bifidobacterium species are anaerobic microorganisms (Scardovi, 1986) and therefore, oxygen toxicity is a critical problem (Shah, 2000). Application of $10 \% \mathrm{CO}_{2}$ had a significant increasing effect

Table 1. Contents of lactobacilli, lactococci, and yeasts in kefir samples during cold storage $(1,7,14$, and $21 \mathrm{~d})$

\begin{tabular}{|c|c|c|c|c|}
\hline Species and sample ${ }^{1}$ & $1 \mathrm{~d}$ & $7 \mathrm{~d}$ & $14 \mathrm{~d}$ & $21 \mathrm{~d}$ \\
\hline \multicolumn{5}{|c|}{ Lactobacillus spp. (log cfu/mL) } \\
\hline KG & $9.21 \pm 0.05^{\mathrm{a}, \mathrm{x}}$ & $9.06 \pm 0.02^{\mathrm{a}, \mathrm{x}}$ & $8.86 \pm 0.03^{\mathrm{b}, \mathrm{x}}$ & $8.03 \pm 0.19^{\mathrm{b}, \mathrm{x}}$ \\
\hline KG-C & $9.28 \pm 0.03^{\mathrm{a}, \mathrm{x}}$ & $9.31 \pm 0.07^{\mathrm{a}, \mathrm{y}}$ & $8.85 \pm 0.04^{\mathrm{b}, \mathrm{x}}$ & $8.29 \pm 0.08^{\mathrm{b}, \mathrm{x}}$ \\
\hline $\mathrm{KS}$ & $9.27 \pm 0.04^{\mathrm{a}, \mathrm{x}}$ & $9.26 \pm 0.03^{\mathrm{a}, \mathrm{y}}$ & $9.06 \pm 0.06^{\mathrm{b}, \mathrm{x}}$ & $8.89 \pm 0.02^{\mathrm{b}, \mathrm{y}}$ \\
\hline KS-C & $9.27 \pm 0.04^{\mathrm{a}, \mathrm{x}}$ & $9.22 \pm 0.04^{\mathrm{a}, \mathrm{y}}$ & $9.00 \pm 0.08^{\mathrm{b}, \mathrm{x}}$ & $9.00 \pm 0.07^{\mathrm{b}, \mathrm{y}}$ \\
\hline \multicolumn{5}{|c|}{ Lactococcus spp. $(\log \mathrm{cfu} / \mathrm{mL})$} \\
\hline KG & $9.23 \pm 0.04^{\mathrm{a}, \mathrm{x}}$ & $9.07 \pm 0.04^{\mathrm{a}, \mathrm{x}}$ & $8.71 \pm 0.08^{\mathrm{b}, \mathrm{x}}$ & $8.04 \pm 0.18^{\mathrm{b}, \mathrm{x}}$ \\
\hline KG-C & $9.26 \pm 0.03^{\mathrm{a}, \mathrm{x}}$ & $9.27 \pm 0.08^{\mathrm{a}, \mathrm{y}}$ & $8.83 \pm 0.01^{\mathrm{b}, \mathrm{x}}$ & $8.30 \pm 0.11^{\mathrm{b}, \mathrm{x}}$ \\
\hline $\mathrm{KS}$ & $9.29 \pm 0.06^{\mathrm{a}, \mathrm{x}}$ & $9.38 \pm 0.06^{\mathrm{a}, \mathrm{y}}$ & $9.17 \pm 0.02^{\mathrm{b}, \mathrm{x}}$ & $8.92 \pm 0.02^{\mathrm{b}, \mathrm{y}}$ \\
\hline KS-C & $9.27 \pm 0.06^{\mathrm{a}, \mathrm{x}}$ & $9.19 \pm 0.03^{\mathrm{a}, \mathrm{y}}$ & $9.07 \pm 0.02^{\mathrm{b}, \mathrm{x}}$ & $9.02 \pm 0.05^{\mathrm{b}, \mathrm{y}}$ \\
\hline \multicolumn{5}{|l|}{ Yeasts (log cfu/mL) } \\
\hline $\mathrm{KG}$ & $5.50 \pm 0.03^{\mathrm{a}, \mathrm{x}}$ & $5.37 \pm 0.06^{\mathrm{a}, \mathrm{x}}$ & $5.07 \pm 0.03^{\mathrm{b}, \mathrm{x}}$ & $5.32 \pm 0.02^{\mathrm{a}, \mathrm{x}}$ \\
\hline KG-C & $5.53 \pm 0.03^{\mathrm{a}, \mathrm{x}}$ & $5.52 \pm 0.02^{\mathrm{a}, \mathrm{x}}$ & $5.37 \pm 0.11^{\mathrm{a}, \mathrm{x}}$ & $5.56 \pm 0.07^{\mathrm{a}, \mathrm{x}}$ \\
\hline $\mathrm{KS}$ & $4.77 \pm 0.13^{\mathrm{a}, \mathrm{y}}$ & $4.81 \pm 0.04^{\mathrm{a}, \mathrm{y}}$ & $4.91 \pm 0.10^{\mathrm{a}, \mathrm{x}}$ & $5.00 \pm 0.09^{\mathrm{a}, \mathrm{x}}$ \\
\hline KS-C & $4.71 \pm 0.07^{\mathrm{a}, \mathrm{y}}$ & $5.15 \pm 0.22^{\mathrm{a}, \mathrm{x}}$ & $5.03 \pm 0.22^{\mathrm{a}, \mathrm{x}}$ & $4.98 \pm 0.15^{\mathrm{a}, \mathrm{x}}$ \\
\hline
\end{tabular}

$\overline{\mathrm{a}, \mathrm{b}}$ Means in the same row with different superscript letters are significantly different $(P<0.05)$.

${ }^{\mathrm{x}, \mathrm{y}}$ Means in the same column within a species with different superscript letters are significantly different $(P<$ $0.05)$.

${ }^{1} \mathrm{KG}=$ kefir produced from kefir grains at normal atmosphere, $\mathrm{KG}-\mathrm{C}=$ kefir produced from kefir grains in $10 \%$ $\mathrm{CO}_{2}$ atmosphere, $\mathrm{KS}=$ kefir produced from natural kefir starter culture at normal atmosphere, and KS-C = kefir produced from natural kefir starter culture in $10 \% \mathrm{CO}_{2}$ atmosphere. 
on L. acidophilus and Bifidobacterium spp. counts in kefir $(P<0.05)$. For maximal therapeutic benefit, the minimum level of probiotic bacteria in yogurt should be $\log 5$ to $\log 6$ viable cells (Robinson, 1987). High levels (at least $10^{6} / \mathrm{g}$ or $10^{6} / \mathrm{mL}$ ) of live microorganisms are recommended for probiotic products (Kurmann and Rasic, 1991). Kefir should be considered as a natural probiotic product because of its high contents of beneficial microorganisms. At the end of the $21 \mathrm{~d}$ of cold storage, the microflora of kefir was stable in both $\mathrm{KG}$ and KS samples.

\section{Chemical Analysis of Kefir Samples}

Table 2 presents the main chemical properties of kefir samples. Kefir samples were produced with $0.1 \%$ fat milk. The $\mathrm{pH}$ values of samples ranged between 4.47 and 4.53 on $\mathrm{d} 1$ and decreased during storage, as occurs
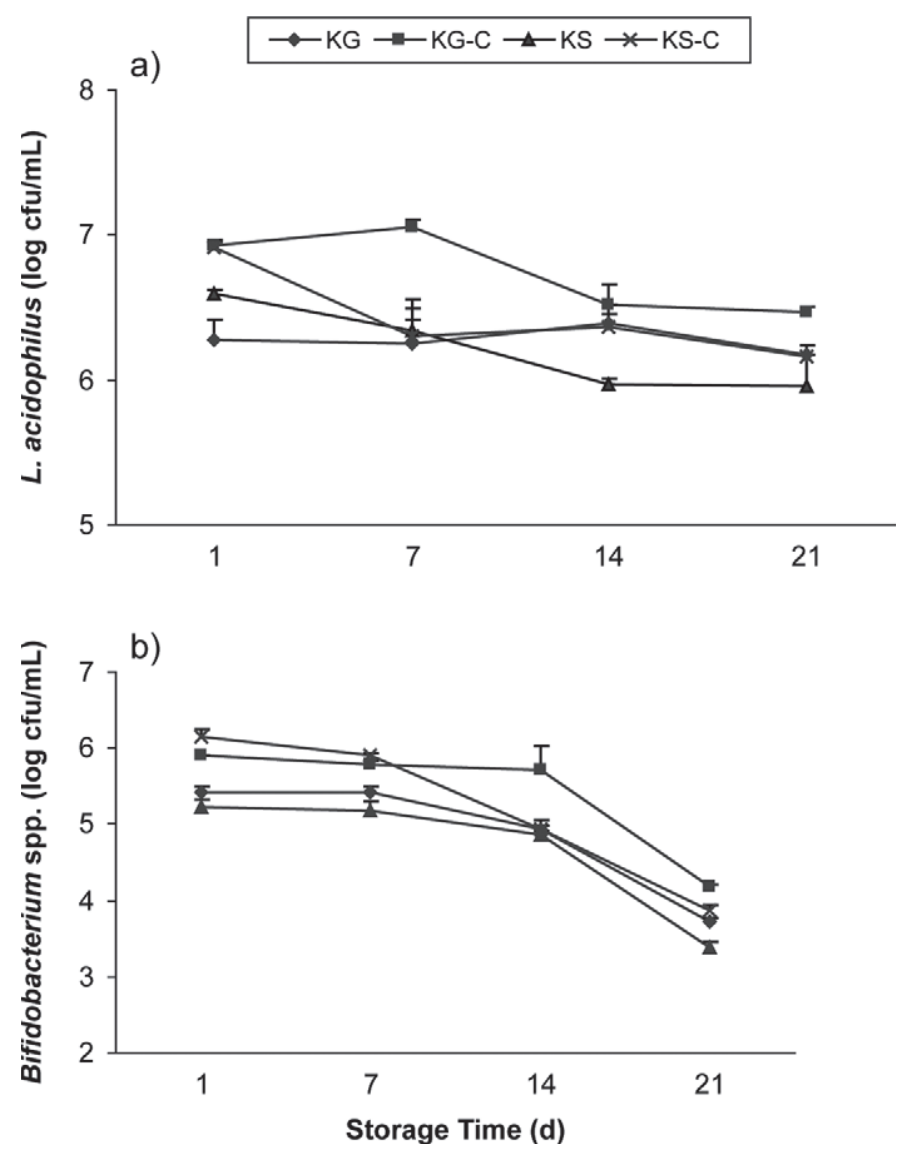

Figure 2. Content of (a) Lactobacillus acidophilus and (b) Bifidobacterium spp. in samples during cold storage for $21 \mathrm{~d}$. $\mathrm{KG}=$ kefir produced from kefir grains at normal atmosphere, $\mathrm{KG}-\mathrm{C}=$ kefir produced from kefir grains in $10 \% \mathrm{CO}_{2}$ atmosphere, $\mathrm{KS}=$ kefir produced from natural kefir starter culture at normal atmosphere, and $\mathrm{KS}-\mathrm{C}=$ kefir produced from natural kefir starter culture in $10 \% \mathrm{CO}_{2}$ atmosphere. in other fermented milks such as yogurt (Abraham-Sen and Holmen, 1981; Katsiari et al., 2002). Collar (1996) found that LAB multiply and produce lactic and acetic acids more slowly in the presence of yeasts than in pure culture. Upon evaluation of the results, we determined that the percentages of kefir grain and natural kefir starter culture used in the study were appropriate (chemical results of the samples were similar; therefore, the use of natural kefir starter culture provides convenience in industry).

Titratable acidity (calculated as lactic acid) and DM values of kefir samples did not differ significantly with treatment $(P>0.05$; Table 2$)$. Dry matter values of KG, KG-C, KS, and KS-C kefir samples at d 1 were $7.98,8.06,8.19$ and 8.21 , respectively (Table 2); these values were lower than in other studies because our kefir samples were produced from fat-free milk (Gambelli et al., 1999; Garrote et al., 2001).

Protein contents of samples on d 1 ranged between 3.43 and $3.48 \mathrm{~g} / 100 \mathrm{~mL}$ (Table 2) and did not differ significantly among kefir samples $(P>0.05)$. Being dependent on the protein content of milk, protein values of kefir samples were $3.3 \mathrm{~g} / 100 \mathrm{~mL}$ in other studies (Renner and Renz-Schaven, 1986; Hallé et al., 1994).

Acetaldehyde contents of kefir samples ranged from 3.8 to $23.6 \mathrm{mg} / \mathrm{L}$ during storage (Table 2). Beshkova et al. (2003) reported that acetaldehyde synthesis was more intensive in kefir samples made with starter culture blends, with a maximum concentration of 18.3 $\mu \mathrm{g} / \mathrm{g}$ compared with $9.5 \mu \mathrm{g} / \mathrm{g}$ in kefir samples made with starter culture blends and kefir grains. A comparatively lower level of acetaldehyde in kefir made with kefir grains was reported (Guzel-Seydim et al., 2000). In our study, ethanol contents of kefir samples ranged from 76.5 to $5,147 \mathrm{mg} / \mathrm{L}$ during storage. Acetaldehyde content of yogurt decreases during storage because alcohol dehydrogenase converts acetaldehyde to ethanol (Marshall and Tamime, 1997). Ertekin and Guzel-Seydim (2010) reported that the non-fat kefir sample had the lowest ethanol content $(160.24 \mathrm{mg} / \mathrm{L})$ compared with other samples (use of inulin in kefir and use of whey protein in kefir) on d 1 . On d 7, ethanol contents ranged between 151.46 and $266.76 \mathrm{mg} / \mathrm{L}$ in all their samples. Ethanol concentrations of 2 kefir samples made with starter culture blends and kefir grains were 4,006 and $2,998 \mathrm{mg} / \mathrm{L}$ after $24 \mathrm{~h}$ of fermentation, and 4,010 and $3,100 \mathrm{mg} / \mathrm{L}$ after $7 \mathrm{~d}$ of storage, respectively (Beshkova et al., 2003).

\section{EPS Content of Kefir}

The EPS content of the samples are presented in Table 3. At the beginning of storage, the EPS contents of the $\mathrm{KG}$ and $\mathrm{KG}-\mathrm{C}$ samples were remarkably 
Table 2. Change in chemical composition of kefir samples during cold storage for $21 \mathrm{~d}$

\begin{tabular}{|c|c|c|c|c|c|c|}
\hline $\begin{array}{l}\text { Sample }^{1} \text { and } \\
\text { storage time }\end{array}$ & $\mathrm{pH}$ & $\begin{array}{c}\mathrm{DM} \\
(\% \mathrm{wt} / \mathrm{wt})\end{array}$ & $\begin{array}{c}\text { Protein } \\
(\mathrm{g} / 100 \mathrm{~mL})\end{array}$ & $\begin{array}{c}\text { Lactic } \\
\text { acid }(\%)\end{array}$ & $\begin{array}{l}\text { Ethanol } \\
(\mathrm{mg} / \mathrm{L})\end{array}$ & $\begin{array}{c}\text { Acetaldehyde } \\
(\mathrm{mg} / \mathrm{L})\end{array}$ \\
\hline \multicolumn{7}{|l|}{$\mathrm{KG}$} \\
\hline $1 \mathrm{~d}$ & $4.47 \pm 0.02^{\mathrm{a}}$ & $7.98 \pm 0.04^{\mathrm{a}}$ & $3.47 \pm 0.02^{\mathrm{a}}$ & $0.89 \pm 0.01^{\mathrm{a}}$ & $111.3 \pm 0.11^{\mathrm{a}}$ & $3.8 \pm 0.28^{\mathrm{a}}$ \\
\hline $14 \mathrm{~d}$ & $4.31 \pm 0.01^{\mathrm{b}}$ & $7.86 \pm 0.13^{\mathrm{a}}$ & $3.30 \pm 0.01^{\mathrm{b}}$ & $0.89 \pm 0.01^{\mathrm{a}}$ & $2,722 \pm 0.91^{\mathrm{c}}$ & $13.9 \pm 0.61^{\mathrm{c}}$ \\
\hline $21 \mathrm{~d}$ & $4.29 \pm 0.00^{\mathrm{b}}$ & $7.86 \pm 0.04^{\mathrm{a}}$ & $3.09 \pm 0.03^{b}$ & $0.92 \pm 0.00^{\mathrm{a}}$ & $4,243.9 \pm 0.4^{\mathrm{d}}$ & $23.6 \pm 0.98^{\mathrm{d}}$ \\
\hline \multicolumn{7}{|l|}{$\mathrm{KG}-\mathrm{C}$} \\
\hline $21 \mathrm{~d}$ & $4.32 \pm 0.02^{\mathrm{b}}$ & $7.81 \pm 0.09^{\mathrm{a}}$ & $3.19 \pm 0.05^{\mathrm{b}}$ & $0.95 \pm 0.01^{\mathrm{a}}$ & $5,147 \pm 0.97^{\mathrm{d}}$ & $21.9 \pm 1.57^{\mathrm{d}}$ \\
\hline \multicolumn{7}{|l|}{$\mathrm{KS}$} \\
\hline $1 \mathrm{~d}$ & $4.49 \pm 0.00^{\mathrm{a}}$ & $8.19 \pm 0.09^{\mathrm{a}}$ & $3.45 \pm 0.02^{\mathrm{a}}$ & $0.81 \pm 0.01^{\mathrm{a}}$ & $97.4 \pm 0.56^{\mathrm{a}}$ & $3.9 \pm 0.99^{\mathrm{a}}$ \\
\hline $7 \mathrm{~d}$ & $4.39 \pm 0.02^{\mathrm{a}}$ & $8.14 \pm 0.12^{\mathrm{a}}$ & $3.43 \pm 0.00^{\mathrm{a}}$ & $0.82 \pm 0.03^{\mathrm{a}}$ & $396.9 \pm 0.3^{\mathrm{b}}$ & $6.3 \pm 0.8^{\mathrm{b}}$ \\
\hline $14 \mathrm{~d}$ & $4.36 \pm 0.03^{\mathrm{b}}$ & $8.10 \pm 0.08^{\mathrm{a}}$ & $3.40 \pm 0.07^{\mathrm{a}}$ & $0.93 \pm 0.02^{\mathrm{a}}$ & $597.3 \pm 1.78^{\mathrm{c}}$ & $9.5 \pm 1.23^{\mathrm{c}}$ \\
\hline $21 \mathrm{~d}$ & $4.35 \pm 0.01^{\mathrm{b}}$ & $7.99 \pm 0.01^{\mathrm{a}}$ & $3.19 \pm 0.13^{\mathrm{a}}$ & $0.92 \pm 0.02^{\mathrm{a}}$ & $3,282.2 \pm 1.23^{\mathrm{d}}$ & $16.5 \pm 0.67^{\mathrm{d}}$ \\
\hline \multicolumn{7}{|c|}{$0,202.2 \perp 1.20$} \\
\hline
\end{tabular}

${ }^{\mathrm{a}-\mathrm{d}}$ Means in the same row within a sample type with different superscript letters are significantly different $(P<0.05)$.

${ }^{1} \mathrm{KG}=$ kefir produced from kefir grains at normal atmosphere, $\mathrm{KG}-\mathrm{C}=$ kefir produced from kefir grains in $10 \% \mathrm{CO}_{2}$ atmosphere, $\mathrm{KS}=$ kefir produced from natural kefir starter culture at normal atmosphere, and $\mathrm{KS}-\mathrm{C}=$ kefir produced from natural kefir starter culture in $10 \% \mathrm{CO}_{2}$ atmosphere.

higher compared with those of KS and KS-C (107.80 and $130.15 \mathrm{mg} / \mathrm{L}$ vs. 79.05 and $85.72 \mathrm{mg} / \mathrm{L})$. Throughout storage, the EPS content of the samples decreased significantly $(P<0.05)$. Although fermentation under $10 \% \mathrm{CO}_{2}$ did not affect rheological properties of the kefir samples, the EPS contents of KG-C and KS-C were higher than their counterparts incubated in the absence of $\mathrm{CO}_{2}$. The EPS content of the sample KG-C, for example, was $20.87 \%$ higher than that of the sample KG $(P<0.05)$.

One logical explanation for the decrease in EPS content of kefir samples may be the hydrolyzation of polysaccharide into its monomers by enzymatic degradation. Ramachandran and Shah (2009) demonstrated that the EPS content of ropy yogurts decreased remarkably during d 21 of cold storage. However, Doleyres et al. (2005) found no difference between the EPS contents of ropy yogurts during 4 wk of storage. This contradiction may be explained by the differences in enzymes that are capable of degrading EPS in both studies. Another possible reason might be changes in the physical parameters of culture during extended fermentation or cold storage (Dierksen et al., 1997). However, in the present study, the trend of decrease in the EPS levels of the samples was similar and independent of fermentation conditions; therefore, we likely cannot attribute the decrease in EPS only to changes in culture parameters during cold storage. Future studies should concentrate on the development of methods to increase the EPS level of kefir during fermentation and to limit the decrease during cold storage.

\section{Rheological Characteristics of Kefir}

Viscosity values of the kefir samples produced under different fermentation conditions are presented in Table

Table 3. Exopolysaccharide content $(\mathrm{mg} / \mathrm{L})$ of kefir samples during cold storage for $21 \mathrm{~d}$

\begin{tabular}{lcccc}
\hline Sample $^{1}$ & $1 \mathrm{~d}$ & $7 \mathrm{~d}$ & $14 \mathrm{~d}$ & $21 \mathrm{~d}$ \\
\hline $\mathrm{KG}$ & $107.80 \pm 11.44^{\mathrm{a}, \mathrm{A}}$ & $76.40 \pm 8.54^{\mathrm{b}, \mathrm{A}}$ & $60.45 \pm 7.54^{\mathrm{c}, \mathrm{A}}$ & $56.48 \pm 5.04^{\mathrm{c}, \mathrm{A}}$ \\
$\mathrm{KG}-\mathrm{C}$ & $130.15 \pm 11.93^{\mathrm{a}, \mathrm{B}}$ & $92.99 \pm 2.93^{\mathrm{b}, \mathrm{B}}$ & $72.31 \pm 1.06^{\mathrm{c}, \mathrm{B}}$ & $54.92 \pm 0.75^{\mathrm{d}, \mathrm{A}}$ \\
$\mathrm{KS}$ & $79.05 \pm 7.51^{\mathrm{a}, \mathrm{C}}$ & $74.96 \pm 5.27^{\mathrm{b}, \mathrm{A}}$ & $68.14 \pm 2.08^{\mathrm{b}, \mathrm{B}}$ & $65.72 \pm 4.70^{\mathrm{c}, \mathrm{B}}$ \\
$\mathrm{KS}-\mathrm{C}$ & $85.72 \pm 7.35^{\mathrm{a}, \mathrm{C}}$ & $80.68 \pm 2.16^{\mathrm{b}, \mathrm{A}}$ & $78.67 \pm 3.35^{\mathrm{c}, \mathrm{C}}$ & $61.93 \pm 7.70^{\mathrm{d}, \mathrm{B}}$ \\
${ }^{\mathrm{a}-\mathrm{d}}$ Means in the same row with different superscript letters are significantly different $(P<0.05)$. \\
${ }^{\mathrm{A}-\mathrm{D}}$ Means in the same column with different superscript letters are significantly different $(P<0.05)$. \\
${ }^{1} \mathrm{KG}=$ kefir produced from kefir grains at normal atmosphere, KG-C = kefir produced from kefir grains in $10 \%$ \\
$\mathrm{CO}_{2}$ atmosphere, KS = kefir produced from natural kefir starter culture at normal atmosphere, and KS-C = \\
kefir produced from natural kefir starter culture in $10 \% \mathrm{CO}_{2}$ atmosphere.
\end{tabular}


Table 4. Viscosity ( $\mathrm{mPa} \cdot \mathrm{s})$ of kefir samples during cold storage for $21 \mathrm{~d}$

\begin{tabular}{|c|c|c|c|c|}
\hline Sample ${ }^{1}$ & $1 \mathrm{~d}$ & $7 \mathrm{~d}$ & $14 \mathrm{~d}$ & $21 \mathrm{~d}$ \\
\hline $\begin{array}{l}\text { KG } \\
\text { KG-C } \\
\text { KS } \\
\text { KS-C }\end{array}$ & $\begin{array}{l}225.0^{\mathrm{a}, \mathrm{A}} \\
227.3^{\mathrm{a}, \mathrm{A}} \\
312.7^{\mathrm{a}, \mathrm{B}} \\
315.2^{\mathrm{a}, \mathrm{B}}\end{array}$ & $\begin{array}{l}202.0^{\mathrm{a}, \mathrm{A}} \\
199.0^{\mathrm{a}, \mathrm{A}} \\
294.3^{\mathrm{a}, \mathrm{B}} \\
281.9^{\mathrm{a}, \mathrm{A}}\end{array}$ & $\begin{array}{l}225.0^{\mathrm{a}, \mathrm{A}} \\
187.0^{\mathrm{a}, \mathrm{A}} \\
316.2^{\mathrm{a}, \mathrm{B}} \\
270.5^{\mathrm{a}, \mathrm{A}}\end{array}$ & $\begin{array}{l}247.0^{\mathrm{a}, \mathrm{A}} \\
171.9^{\mathrm{a}, \mathrm{A}} \\
292.5^{\mathrm{a}, \mathrm{B}} \\
284.3^{\mathrm{a}, \mathrm{B}}\end{array}$ \\
\hline
\end{tabular}

4. The viscosity of the kefir samples ranged between 225 and $315.2 \mathrm{mPa} \cdot \mathrm{s}$ on $\mathrm{d} 1$. At the beginning of storage, the viscosity values of the samples were found to be independent of fermentation under $\mathrm{CO}_{2}$ atmosphere. In contrast, samples fermented with natural kefir culture (KS and KS-C) had higher viscosity than those made with kefir grains (KG and KG-C; $P<0.05$ ). A similar trend was observed during d 21 of storage at $4^{\circ} \mathrm{C}$. With the exception of $\mathrm{KG}$, the viscosity values of the kefir samples decreased after $21 \mathrm{~d}$, being still higher in KS and KS-C than in other kefir samples. Similar observations were made by other researchers (Thompson et al., 1990; Irigoyen et al., 2005). Garote et al. (1998) observed a decrease in viscosity during cold storage even at high grain to milk ratios. Because the decrease in viscosity was independent of fermentation parameters and the source of kefir starter microflora in the current study, this decrease may be explained by the hydrolyzation of EPS into its monomers by glycohydrolases (Degeest et al., 2002; Purwandari et al., 2007). Pham et al. (2000) demonstrated that glycohydrolases were capable of lowering the viscosity of the polymers produced by Lactobacillus rhamnosus, as well as liberating some reducing sugars. The decrease in viscosity in polymers is observed during extended fermentation (over $24 \mathrm{~h}$ ) and continues during cold storage. Similarly, Bensmira et al. (2010) demonstrated that during extended fermentation period $(>30 \mathrm{~h})$, the amount of EPS produced by kefir microflora decreases. Unlike our findings, the decrease in EPS level in kefir as a function of fermentation temperature, time, and homogenization of milk did not lead to decrease in complex viscosity $\left(\eta^{*}\right)$ and loss modulus $\left(\mathrm{G}^{\prime \prime}\right)$ values of kefir samples (Bensmira et al., 2010). Bacterial EPS are known to interact with milk proteins and improve viscoelastic properties of weak gels such as yogurt (Vlahapoulou et al., 2001). Therefore, we can assume that a reduction in EPS level may have led to a decrease in viscosity values of the kefir samples in the current study.

To determine the time-dependent flow behavior of the kefir samples, we determined the apparent viscosity and shear rate. After fermentation $(\sim 24 \mathrm{~h})$, the kefir samples exhibited non-Newtonian pseudoplastic fluid behavior according to the power-law model $\left(\mathrm{R}^{2}\right.$ $=0.99$; Figure 3a). With the increase in shear rate, the apparent viscosity values of the samples decreased, demonstrating thixotrophy (shear thinning). All kefir samples had similar rheological characteristics during the storage period, and neither the effect of fermentation under modified atmosphere nor the source of
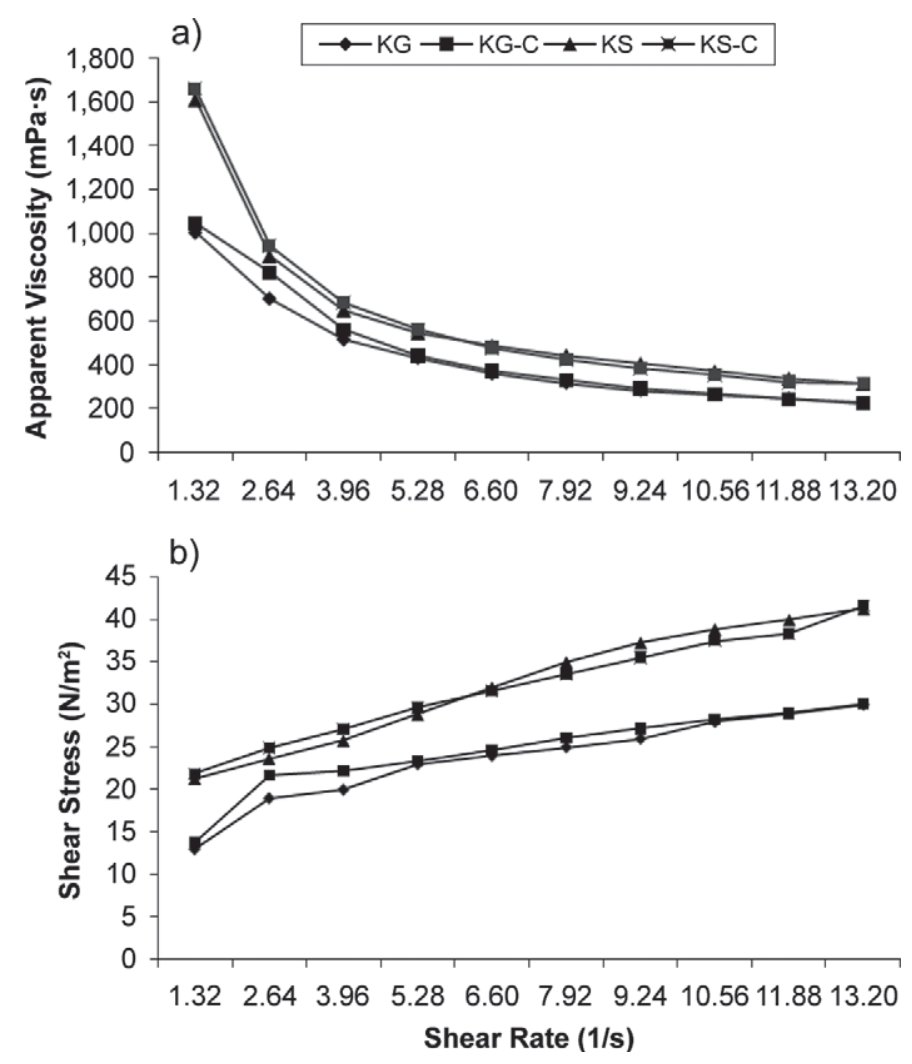

Figure 3. (a) Apparent viscosity as a function of shear rate of kefir samples on d 1; (b) shear stress as a function of shear rate of kefir samples on d $1 . \mathrm{KG}=$ kefir produced from kefir grains at normal atmosphere, KG-C = kefir produced from kefir grains in $10 \% \mathrm{CO}_{2}$ atmosphere, $\mathrm{KS}=$ kefir produced from natural kefir starter culture at normal atmosphere, and $\mathrm{KS}-\mathrm{C}=$ kefir produced from natural kefir starter culture in $10 \% \mathrm{CO}_{2}$ atmosphere. 
starter microorganisms affected the pseudoplastic flow behavior. Loose physical contacts between proteins as a result of weak electrostatic and hydrophobic bonding are expected to lead to shear-thinning behavior in liquid fermented milks (Abu Jdayil and Mohammed, 2002). In the current study, high water level and a timedependent decrease in EPS content of kefir resulted in non-Newtonian shear-thinning behavior (Figure 3b). Overall, KS and KS-C had higher shear stress values as a function of shear rate than KG and KG-C. Similar results were reported for kefir (Ertekin and GuzelSeydim, 2010), ayran (Koksoy and Kılıç, 2003), lactic beverages (Penna et al., 2001), and buttermilk (Kristensen et al., 1997).

\section{Sensory Evaluation of Kefir Samples}

The sensory evaluation results of kefir samples on $\mathrm{d}$ 1, 7, and 14 are given in Table 5 . The shelf life of kefir was complete at d 21 in a preliminary test. Therefore, the sensory storage period of the study was determined to be $14 \mathrm{~d}$. The KS-C sample on d 1 had the best appearance, with a mean score of 9.9 (Table 5), and odor, with a mean score of 9.4 in the KS-C kefir samples on d 1, 7, and 14 (Table 5). The KG and KG-C samples had mean texture scores of 7.8 and 8.1, and KS and KS-C samples had mean texture scores of 9.3 and 9.5 points on d 14, respectively (Table 5). The KG, KG-C, KS and KS-C samples had mean scores for texture of 7.9, 8.2, 9.0 and 9.5 on $\mathrm{d} 7$, respectively (Table 5). According to the sensory analysis results, KS samples were more liked than KG samples $(P<0.05)$. Applications of dif- ferent atmosphere conditions to $\mathrm{KS}$ and $\mathrm{KG}$ samples were statistically insignificant $(P>0.05)$ in terms of aroma and flavor.

In overall acceptability, KS and KS-C samples had numerically higher scores than KG and KG-C samples on $\mathrm{d} 1(P>0.05)$. According to the results of the overall evaluation, starter samples had higher scores throughout the storage period compared with grain samples.

Based on the microbial and sensory results, the suggested shelf life of kefir produced from natural kefir grains is $14 \mathrm{~d}$. Kefir grains are propagated using traditional methods, which are not easy to replicate in industrial production. This study presents significant findings with regard to probiotic content and microflora of kefir, which are arguably the most important criteria for its therapeutic efficacy. These findings provide significant contributions not only to the literature, but also to the dairy industry.

\section{CONCLUSIONS}

Kefir samples produced with kefir grains and from natural kefir starter culture without grains had similar chemical, microbiological, rheological, and sensory properties. Use of kefir starter culture without grains is easier and more applicable than the maintenance of kefir grains on the industrial scale. The therapeutic properties of kefir are attributed to the physiological and health-promoting properties of EPS (mainly kefiran). In this respect, the relatively higher EPS content in the samples fermented under $10 \% \mathrm{CO}_{2}$ provides an additional advantage.

Table 5. Sensory evaluation ${ }^{1}$ of kefir samples during cold storage $(n=12)$ for $14 \mathrm{~d}$

\begin{tabular}{|c|c|c|c|c|c|}
\hline $\begin{array}{l}\text { Sample }^{2} \text { and } \\
\text { storage time }\end{array}$ & Appearance & Odor & $\begin{array}{c}\text { Aroma } \\
\text { and flavor }\end{array}$ & Texture & $\begin{array}{c}\text { Overall } \\
\text { acceptability }\end{array}$ \\
\hline \multicolumn{6}{|l|}{ KG } \\
\hline $1 \mathrm{~d}$ & $8.4 \pm 0.53$ & $8.7 \pm 0.29$ & $7.8 \pm 0.50$ & $8.1 \pm 0.35$ & $7.7 \pm 0.17$ \\
\hline $7 \mathrm{~d}$ & $8.9 \pm 0.31$ & $9.1 \pm 0.36$ & $7.6 \pm 0.34$ & $7.9 \pm 0.34$ & $7.3 \pm 0.33$ \\
\hline $14 \mathrm{~d}$ & $8.0 \pm 0.55$ & $6.4 \pm 0.25$ & $4.1 \pm 0.37$ & $7.8 \pm 0.52$ & $3.0 \pm 0.47$ \\
\hline \multicolumn{6}{|l|}{ KG-C } \\
\hline $1 \mathrm{~d}$ & $8.2 \pm 0.46$ & $8.7 \pm 0.33$ & $7.9 \pm 0.39$ & $8.2 \pm 0.22$ & $7.9 \pm 0.11$ \\
\hline $7 \mathrm{~d}$ & $9.0 \pm 0.32$ & $8.7 \pm 0.43$ & $7.5 \pm 0.33$ & $8.2 \pm 0.32$ & $7.4 \pm 0.26$ \\
\hline $14 \mathrm{~d}$ & $8.1 \pm 0.50$ & $7.9 \pm 0.27$ & $5.3 \pm 0.41$ & $8.1 \pm 0.32$ & $4.8 \pm 0.24$ \\
\hline \multicolumn{6}{|l|}{ KS } \\
\hline $1 \mathrm{~d}$ & $9.8 \pm 0.24$ & $9.2 \pm 0.41$ & $9.1 \pm 0.35$ & $9.3 \pm 0.29$ & $9.2 \pm 0.15$ \\
\hline $7 \mathrm{~d}$ & $9.2 \pm 0.28$ & $9.1 \pm 0.33$ & $8.6 \pm 0.32$ & $9.0 \pm 0.29$ & $8.9 \pm 0.23$ \\
\hline $14 \mathrm{~d}$ & $9.6 \pm 0.08$ & $9.3 \pm 0.21$ & $7.3 \pm 0.48$ & $9.3 \pm 0.24$ & $7.0 \pm 0.22$ \\
\hline \multicolumn{6}{|l|}{ KS-C } \\
\hline $1 \mathrm{~d}$ & $9.9 \pm 0.11$ & $9.3 \pm 0.29$ & $9.3 \pm 0.29$ & $9.4 \pm 0.24$ & $9.7 \pm 0.17$ \\
\hline $7 \mathrm{~d}$ & $9.5 \pm 0.14$ & $9.4 \pm 0.22$ & $9.5 \pm 0.17$ & $9.5 \pm 0.17$ & $9.1 \pm 0.20$ \\
\hline $14 \mathrm{~d}$ & $9.6 \pm 0.18$ & $9.4 \pm 0.18$ & $7.4 \pm 0.31$ & $9.5 \pm 0.22$ & $8.0 \pm 0.13$ \\
\hline
\end{tabular}

${ }^{1}$ Attributes were scored on a 10 -point scale, where $0=$ absence of the attribute and $10=$ extremely high intensity of the attribute.

${ }^{2} \mathrm{KG}=$ kefir produced from kefir grains at normal atmosphere, $\mathrm{KG}-\mathrm{C}=$ kefir produced from kefir grains in $10 \%$ $\mathrm{CO}_{2}$ atmosphere, $\mathrm{KS}=$ kefir produced from natural kefir starter culture at normal atmosphere, and KS-C = kefir produced from natural kefir starter culture in $10 \% \mathrm{CO}_{2}$ atmosphere. 


\section{REFERENCES}

Abrahamsen, R. K., and T. B. Holmen. 1981. Goat's milk yoghurt made from non-homogenized and homogenized milks, concentrated by different methods. J. Dairy Res. 48:457-463.

Abu-Jdayil, B., and H. Mohammed. 2002. Experimental and modelling studies of the flow properties of concentrated yogurt as affected by the storage time. J. Food Eng. 52:359-365.

AOAC International. 1992. Official Methods of Analysis. 14th ed. AOAC International, Arlington, VA.

Bensmira, M., C. Nsabimana, and B. Jiang. 2010. Effects of fermentation conditions and homogenization pressure on the rheological properties of kefir. Lebenson. Wiss. Technol. 43:1180-1184.

Beshkova, D. M., E. D. Simova, G. I. Frengova, Z. I. Simov, and Z. P. Dimitrov. 2003. Production of volatile aroma compounds by kefir starter cultures. Int. Dairy J. 13:529-535.

Cerning, J. 1995. Production of exopolysaccharides by lactic acid bacteria and dairy propionibacteria. Lait 75:463-472.

Cheirsilp, B., H. Shimizu, and S. Shioya. 2003a. Enhanced kefiran production by mixed culture of Lactobacillus kefiranofaciens and Saccharomyces cerevisiae. J. Biotechnol. 100:43-53.

Cheirsilp, B., H. Shoji, H. Shimizu, and S. Shioya. 2003b. Interactions between Lactobacillus kefiranofaciens and Saccharomyces cerevisiae in mixed culture for kefiran production. J. Biosci. Bioeng. 96:279-284.

Collar, C. 1996. Biochemical and technological assessment of the metabolism of pure and mixed cultures of yeast and lactic acid bacteria in breadmaking applications. Food Sci. Technol. Int. $2: 349-367$.

Degeest, B., F. Mozzi, and L. De Vuyst. 2002. Effect of medium composition and temperature and $\mathrm{pH}$ changes on the exopolysaccharide yields and stability during Streptococcus thermophilus LY03 fermentation. Int. J. Food Microbiol. 79:161-166.

Dierksen, K. P., W. E. Sandine, and J. E. Trempy. 1997. Expression of ropy and mucoid phenotypes in Lactococcus lactis. J. Dairy Sci. 80:1528-1536.

Doleyres, Y., L. Schaub, and C. Lacroix. 2005. Comparison of the functionality of exopolysaccharides produced in situ or added as bioingredients on yogurt properties. J. Dairy Sci. 88:4146-4156.

Ertekin, B., and Z. B. Guzel-Seydim. 2010. Effect of fat replacers on kefir quality. J. Sci. Food Agric. 90:543-548.

Frengova, G. I., E. D. Simova, D. M. Beshkova, and Z. I. Simova. 2002. Exopolysaccharides produced by lactic acid bacteria of kefir grain. Z. Naturforsch. C 57:805-810.

Gambelli, L., P. Manzi, G. Panfili, V. Vivanti, and L. Pizzoferrato. 1999. Constituents of nutritional relevance in fermented milk products commercialised in Italy. Food Chem. 66:353-358.

Garote, G. L., A. G. Abraham, and G. L. De Antoni. 1998. Characteristics of kefir prepared with different grain:milk ratios. J. Dairy Res. 65:149-154.

Garrote, G. L., A. G. Abraham, and G. L. De Antoni. 2001. Chemical and microbiological characterisation of kefir grains. J. Dairy Res. 68:639-652.

Guzel-Seydim, Z., T. Kök-Taş, and A. K. Greene. 2010. Kefir and koumiss: Microbiology and technology. Pages 143-163 in Development and Manufacture of Yogurt and Other Functional Dairy Products. F. Ylldiz, ed. CRC Press, Boca Raton, FL.

Guzel-Seydim, Z. B., T. Kök-Tas, and A. K. Greene. 2011. Review: Functional properties of kefir. Crit. Rev. Food Sci. Nutr. 51:261268.

Guzel-Seydim, Z. B., J. Wyffels, A. C. Seydim, and A. K. Greene. 2005. Turkish kefir and kefir grains: Microbial enumeration and electron microscobic observation. Int. J. Dairy Technol. 58:25-29.

Guzel-Seydim, Z. B., A. C. Seydim, and A. K. Greene. 2000. Organic acids and volatile flavor components evolved during refrigerated storage of kefir. J. Dairy Sci. 83:275-277.

Hallé, C., F. Leroi, X. Dousset, and M. Pidoux. 1994. Les kéfirs: Des associations bactéries-levures. Pages 169-182 in Bactéries Lactiques. Vol. 2. E. H. de Roissart and F. M. Luquet, ed. Lorica, Uriage, France.
Irigoyen, A., I. Arana, M. Castiella, P. Torre, and F. C. Ibanez. 2005 Microbiological, physicochemical and sensory characteristics of kefir during storage. Food Chem. 90:613-620.

Kandler, O., and P. Kunath. 1983. Lactobacillus kefir, a component of the microflora of kefir. Syst. Appl. Microbiol. 4:286-294.

Katsiari, M. C., L. P. Voutsinas, and E. Kondyli. 2002. Manufacture of yogurt from stored frozen sheep's milk. Food Chem. 77:413-420.

Kılıç, S., H. Uysal, N. Akbulut, G. Kavas, and H. Kesenkas. 1999 Yeni basslayanlar ve tahıl üretilen olgunlaşma kefir kimyasal, mikrobiyolojik ve duyusal değişiklikler. Ziraat Fakültesi Dergisi $36: 111-118$.

Kök-Taş, T., and Z. B. Güzel-Seydim. 2010. Effects of fat replacers on the quality criteria of probiotic fermented milk. Milchwissenschaft $65: 284-286$

Koksoy, A., and M. Kılıç. 2003. Effects of water and salt level on rheological properties of ayran, a Turkish yoghurt drink. Int. Dairy J. $13: 835-839$.

Kristensen, D., P. Y. Jensen, F. Madsen, and K. S. Birdi. 1997. Rheology and surface, tension of selected processed dairy fluids: Influence of temperature. J. Dairy Sci. 80:2282-2290.

Kurmann, J. A., and J. L. Rasic. 1991. Technology of fermented special products. Fermented Milks: Science and Technology. International Dairy Federation, Brussels, Belgium. IDF Bull. 227:101-109.

Kwon, Y., E. Apostolidis, and K. Shetty. 2006. Anti-diabetes functionality of kefir culture-mediated fermented soymilk supplemented with rhodiola extracts. Food Biotechnol. 20:13-29.

Marshall, V. M. E., and A. Y. Tamime. 1997. Physiology and biochemistry of fermented milks. Pages 153-192 in Microbiology and Biochemistry of Cheese and Fermented Milks. 2nd ed. B. A. Law, ed. Chapman \& Hall, New York, NY.

Meilgaard, M., G. V. Civille, and B. T. Carr. 1999. The spectrum descriptive analysis method. Pages 173-229 in Sensory Evaluation Techniques. CRC Press Inc., Boca Raton, FL.

Micheli, L., D. Uccelletti, C. Palleschi, and V. Crescenzi. 1999. Isolation and characterization of a ropy Lactobacillus strain producing exopolysaccharide kefiran. Appl. Microbiol. Biotechnol. 53:69-74.

Mitsue, T., K. Tachibana, and Y. Fuijo. 1999. Efficient kefiran production by a mixed culture of Lactobacillus kefiranofaciens KF-75 and yeast strains. Seibutsu-kogaku Kaishi 77:99-103.

Mossel, A. A., J. E. L. Corry, C. B. Struijk, and R. M. Baird. 1995 Essentials of the Microbiology of Foods: A Textbook for Advanced Studies. John Wiley \& Sons, Chichester, UK.

Motaghi, M., M. Mazaheri, N. Moazami, M. H. Farkhondeh, and E. M. Goltapeh. 1997. Kefir production in Iran. World J. Microbiol. Biotechnol. 13:579-581.

Penna, A. L. B., K. Sivieri, and M. N. Oliviera. 2001. Relation between quality and rheological properties of lactic beverages. Int. J. Food Eng. 49:7-13.

Pham, P. L., I. Dupont, D. Roy, G. Lapointe, and J. Cerning. 2000 Production of exopolysaccharide by Lactobacillus rhamnosus $\mathrm{R}$ and analysis of its enzymatic degradation during prolonged fermentation. Appl. Environ. Microbiol. 66:2302-2310.

Piermaria, J. A., A. Pinotti, M. A. Garcia, and A. G. Abraham. 2009. Films based on kefiran, an exopolysaccharide obtained from kefir grain: Development and characterization. Food Hydrocoll. 23:684690.

Purwandari, U., N. P. Shah, and T. Vasiljevic. 2007. Effects of exopolysaccharide-producing strains of Streptococcus thermophilus on technological and rheological properties of set-type yogurt. Int. Dairy J. 17:1344-1352.

Ramachandran, L., and N. P. Shah. 2009. Effect of exopolysaccharides and inulin on the proteolytic, angiotensin-I-converting enzymeand $\alpha$-glucosidase-inhibitory activities as well as on textural and rheological properties of low-fat yogurt during refrigerated storage. Dairy Sci. Technol. 89:583-600.

Rea, M. C., T. Lennartsson, P. Dillon, F. D. Drinan, W. J. Reville, M. Heapes, and T. M. Cogan. 1996. Irish kefir-like grains: Their structure, microbial composition and fermentation kinetics. J. Appl. Bacteriol. 81:83-94. 
Renner, E., and A. Renz-Schaven. 1986. Nahrwerttabellen für Milch und Milchprodukte. Verlag B. Renner, Köhner K. G. Giessen, Germany.

Rimada, P. S., and A. G. Abraham. 2001. Polysaccharide production by kefir grains during whey fermentation. J. Dairy Res. 68:653661.

Rimada, P. S., and A. G. Abraham. 2006. Kefiran improves rheological properties of glucono- $\delta$-lactone induced skim milk gels. Int. Dairy J. $16: 33-39$.

Robinson, R. K. 1987. Survival of Lactobacillus acidophilus in fermented products. Suid Afrikaanse Tydskrif Vir Suiwelkunde. 19:25-27.

Rosi, J., and J. Rossi. 1978. I Microrganismi del kefir: I fermenti lattici. Sci. Tecn. Latt. Cas. 29:291-305.

Scardovi, V. 1986. Genus Bifidobacterium. Pages 1418-1434 in Bergey's Manual of Systematic Bacteriology. Vol. 2. P. H. Sheath, N. S. Mair, M. E. Sharpe, and J. G. Holt, ed. Williams and Wilkins Publ., Baltimore, MD.

Shah, N. P. 2000. Probiotic bacteria: Selective enumeration and survival in dairy foods. J. Dairy Sci. 83:894-907.

Simova, E., D. Beshkova, A. Angelov, T. Hristozova, G. Frengova, and Z. Spasov. 2002. Lactic acid bacteria and yeasts in kefir grains and kefir made from them. J. Ind. Microbiol. Biotechnol. 28:1-6.

Thompson, J. K., D. E. Johnston, R. J. Murphy, and M. A. Collins. 1990. Characteristics of milk fermentation from rural Northern Irealnd which resembles kefir. Irish J. Food Sci. Technol. 14:34-49.

Uysal, H., O. Kinik, and G. Kavas. 2004. Sensory Test Techiques in Dairy Products. Ege University, Izmir, Turkey.
Vlahapoulou, I., A. E. Bell, and R. A. Wilbey. 2001. Effects of starter culture and its exopolysaccharides on the gelation of glucono- $\delta$ lactone-acidified bovine and caprine milk. Int. J. Dairy Technol. 54:135-140.

Wang, S. Y., H. Chen, J. R. Liu, and M. J. Chen. 2008. Identification of yeasts and evaluation of their distribution in Taiwanese kefir and viili starters. J. Dairy Sci. 91:3798-3805.

Witthuhn, R. C., T. Schoeman, and T. J. Britz. 2004. Isolation and characterization of the microbial population of different South African kefir grains. Int. J. Dairy Technol. 57:383-389.

WonHo, Y., N. YoungMi, and K. ChangHan. 2003. Antimicrobial and antitumoral actvities of Candida kefyr TFP 7 isolated from Tibetian fermented milk. Korean J. Food Sci. Anim. Res. 23:80-85.

Wszolek, M., B. Kupiec-Teahan, H. Skoz Guldager, and A. Y. Tamime. 2006. Production of kefir, koumiss and other related products. Pages 174-216 in Fermented Milks. A. Y. Tamime, ed. Blackwell Publishing, Ames, IA.

Yoon, Y. H., J. K. Cho, Y. J. Baek, and C. S. Huh. 1999. Antimutagenic activity of Lactobacillus spp. isolated from kefir, yoghurt and non-starter strains. Korean J. Anim. Sci. 41:39-44.

Zisu, B., and N. P. Shah. 2003. Effects of pH, temperature, supplementation with whey protein concentrate, and adjunct cultures on the production of exopolysaccharides by Streptococcus thermophilus 1275. J. Dairy Sci. 86:3405-3415 